\title{
Test Anxiety and Its Relationship to Self-Esteem During the COVID-19 Pandemic
}

\author{
Nawal Hamid Mohammed Hamid ${ }^{1}$ \\ ${ }^{1}$ Department of Education, Faculty of Science and Arts, Northern Border University, Rafha Campus, KSA \\ Correspondence: Nawal Hamid Mohammed Hamid, Department of Education, Faculty of Science and Arts, \\ Northern Border University, Rafha Campus, KSA.
}

Received: September 12, 2021

Accepted: October 4, 2021

Online Published: October 8, 2021

doi:10.5539/ijps.v13n4p15

URL: https://doi.org/10.5539/ijps.v13n4p15

\begin{abstract}
This research aimed to investigate the level of test anxiety and the relationship between test anxiety and self-esteem among the students of the faculty of Science and Arts in Rafha campus, Northern Border University, KSA during the COVID-19 pandemic. In addition, it intended to identify the differences in test anxiety among the students according to gender variable. The researcher applied the descriptive method, prepared a preliminary data form, and used the Westside Test Anxiety Scale by Driscoll (2007) and the Self-esteem Scale by El Sayed (2019). The data were collected online, and the sample size was (336) students. The results showed that the level of test anxiety among the students of the faculty of Science and Arts during the COVID-19 pandemic was high. The correlation coefficient between the impairment subscale and self-esteem was negative but statistically insignificant. Moreover, the correlation coefficients between both the worry subscale and the test anxiety total scores with the self-esteem resulted in a negative sign and statistically significant. There were significant differences in test anxiety among the students in the impairment subscale, the P-value was (0.005), which indicates that the difference between the two means is statistically significant, and the males' mean is greater. While the P-value for the worry subscale was $(0.226)$, which indicates that the difference was insignificant, the P-value of the test anxiety total scores was (0.029), which reveals that the difference between the two means is statistically significant, and the males' mean is greater.
\end{abstract}

Keywords: test anxiety, self-esteem, students of faculty of science and arts, COVID-19 pandemic

\section{Introduction}

Anxiety, to some extent, is needed because it works as a motivator and encourages a student to study hard, but if it is over the normal level, it will affect the performance negatively, as well as the well-being of the student.

In January 2020, the World Health Organization announced the outbreak of a novel coronavirus disease as a Public Health Emergency of International Concern, and in March 2020, stated that the COVID-19 could be characterized as a pandemic. However, this crisis is causing stress among the population across the globe (World Health Organization, 2020). Preliminary data mark that the COVID-19 pandemic might have a great effect on mental health and well-being (Jung et al., 2020). The spread of the novel coronavirus has significantly disrupted every aspect of human life including education. Hence, campuses are closed down, and the teaching-learning process has moved online in many educational institutions around the world (Jena, 2020) aimed at limiting the transmission of the virus.

As exams are an integral part of education, which cannot be denied (Neemati et al., 2014), it is significant to find out the extent the students have obtained the theoretical and practical skills required for both personal and national development (Iliyasu \& Abiodun, 2020). Furthermore, the continuity of a student in education, the grade point average (GPA), the level of his/her qualification and the competitiveness in the labor market depend on performance on examinations. Thus, it is predicted that students' level of test anxiety will increase during the examination period in comparison to other times of the term (Ndirangu et al., 2009). A student with test anxiety may be incapable of concentrating on studies even if he/she intends to study. In addition, even if he/she has studied, he/she cannot remember the information during the exam and makes mistakes (Yüksel et al., 2018).

The COVID-19 pandemic is expected to cause an elevation in anxiety levels all over the world (Arora et al., 2021). Moreover, a research study by Irawati \& Hajat (2012) demonstrated that there were significant and 
positive correlations between self-esteem and learning achievement. Also, a study by Sar1 et al. (2018) revealed that self-esteem and test anxiety levels were negatively correlated. In this regard, Wachelka et al. (1999) state that test anxiety can be greatly significant when it leads to high levels of hardship and academic failure even among capable students. Onyeizugbo (2010) argues that "Gender could possibly predict differences in levels of test anxiety", and Sugiyanto et al. (2020) mention that gender becomes a clear factor that raises the stress level. Therefore, the main objective of the current research is to investigate the level of test anxiety and the relationship between test anxiety and self-esteem among the students as well as identify the differences among the students in test anxiety according to gender variable.

\subsection{Research Problem}

Test anxiety has a significant role in a student's educational, occupational and emotional life (Asghari et al., 2012). It becomes a problem as it affects performance. Moreover, test anxiety could impede students' ability to do well on exams and prevent them from exerting their knowledge. Some students have got good skills and knowledge to excel in the exams, however, their extreme anxiety hinders their performance (Javanbakht \& Hadian, 2014). Also, test anxiety could lead to mental and physical problems (Yoon \& Kwon, 2015). More significantly, the COVID-19 scourge is the current foe of humanity; therefore, one must be aware of correlated effects and be able to respond strongly to the outcomes (Khoshaim et al., 2020). Accordingly, it has become extremely important to explore the negative indicators of students' academic achievements in order to train them to deal effectively with the stress (Singh \& Jha, 2013).

Khoshaim et al. (2020), in their study which focused on anxiety levels among university students during the COVID-19 pandemic in Saudi Arabia, noticed that 35\% of the students experienced moderate to extreme levels of anxiety. Furthermore, Elgendy's (2020) study, which was aimed to examine the effect of using a proposed teaching strategy to reduce test anxiety among College students, proposed that research studies need to be conducted to deal with university students with reference to the variables associated with their personality and academic achievement. In addition, Alqudah \& Rashid (2020) contend that personality contributes to the mental well-being of learners.

The current research problem can be addressed in terms of the following questions:

1) What is the level of test anxiety among the students of the faculty of Science and Arts during the COVID-19 pandemic?

2) Is there a negative correlation between test anxiety and self-esteem among the students of the faculty of Science and Arts during the COVID-19 pandemic?

3) Are there differences in test anxiety among the students of the faculty of Science and Arts during the COVID-19 pandemic according to the gender variable?

\subsection{Research Importance}

The importance of the current research stems from its attempt to investigate test anxiety and its relationship to self-esteem among the students of the faculty of Science and Arts during the COVID-19 pandemic. In addition, the significance of this research comes from the scarcity of research studies that intended to reveal the relationship between test anxiety and self-esteem among university students during the COVID-19 pandemic. In this regard, Zhang et al. (2020) state that less attention has been paid to the negative consequences related to mental health or efficacious alleviation plans to improve mental health.

Previous studies prior to the spread of coronavirus across the globe confirmed the existence of test anxiety among university students. As the COVID-19 pandemic is an extraordinary crisis, it increases the level of test anxiety on top of the anxiety that already existed. Therefore, the current research represents a response to the previous study conducted by Elgendy (2020) which suggested investigation of factors associated with the students' personalities. Furthermore, the practical significance of the current research lies in the possibility of benefiting from its results in revealing the level of test anxiety and its relationship to self-esteem among university students during the COVID-19 pandemic. It is also possible that the concerned institutions could benefit from its results and recommendations in the fields of psychological counseling as well as developing and providing preventive and curative programs.

\subsection{Related Literature Review}

\subsubsection{Test Anxiety}

Anxiety is a common problem all over the world, and it is one of the main barriers to academic performance. Learners with anxiety show a negative attitude in their education: such as the absence of interest in learning, 
poor performance on examinations, and lower academic achievement (Khan et al., 2021). Test anxiety is an unpleasant experience, it affects performance and personal development (Sarason \& Sarason, 1990).

Test anxiety can be defined as a tensed and stressed mental state encountered by students when they think of a test or when they are taking the test (Alqudah \& Rashid, 2020). Fear is rational, but extreme fear intervenes with performance, and many researchers point out that a little worry is good for learners as it keeps their task-oriented; nevertheless, excessive worry can be very debilitating and it influences the results in case not dealt with appropriately (Hashmat et al., 2008). Moreover, a study by Ndirangu et al. (2009) indicated that there is a statistically significant difference between test anxiety levels pre and after examinations, and high anxiety was experienced before the examination.

\subsubsection{Self-Esteem}

Self-esteem is persons' experience that they are appropriate to life and its requirements. Specifically, self-esteem is confidence in the ability to think, deal with the challenges of life; and confidence in the right to be happy, the feeling of being valuable, entitled to confirm one's desires and needs, and enjoy the fruits of his/her efforts. Moreover, self-esteem is an essential human need that makes a fundamental contribution to the life process; that is necessary to normal and healthy development; and has survival-value. Individuals with a decent level of self-esteem are currently needed economically in large numbers (Branden, 1990). High self-esteem prospectively forecasts success and well-being in life (Orth \& Robins, 2014). In addition, research studies among the university students, such as Kharsah \& Fatmawati (2016), Arshad et al. (2015), demonstrate that there was a significant relationship between self-esteem and academic performance.

Self-esteem is a pre-requisite for motivation, it raises the morale of a human being as it develops positive attitudes and self-image. Thus, high self-esteem individuals enjoy performing various activities in their daily life. They are full of positivity and excitement, and they act to find answers to their problems and face challenges in their lives positively. So, they accept themselves as they are, and they are open to change and do not suffer from any inferiority complex. In reverse, persons with low self-esteem are low in confidence and resistant to change (Cheema \& Bhardwaj, 2021).

\subsubsection{The Relationship between Test Anxiety and Self-Esteem}

Self-esteem is an important and strong predictor of test anxiety (von der Embse, 2018). So, People with a high level of self-esteem have great expectations of their performance and they are eager for success. Therefore, they attempt to perform better in learning than the others. Thus, the more an individual faces test anxiety, the less academic achievements he experiences and vice versa (Khaledian, 2013). However, a research study by Fathi-Ashtiani et al. (2007) revealed that self-concept and self-esteem are correlated and have positive effects on increasing academic achievement. Also, the increase of self-concept and self-esteem are related to the reduction of anxiety and there is a negative significant relationship between self-concept, self-esteem, and depression which will result in decreasing academic achievement. Similarly, a research study by Effiom et al. (2018) showed that test anxiety and self-esteem directly significantly affected academic performance.

Since the unprecedented spread of the coronavirus globally, several research studies have been concentrated to investigate test anxiety among university students during this pandemic. These studies include, for instance, a research study conducted by Park \& Byun (2021) among nurse students confirmed that there was a negative correlation between test anxiety and self-esteem. Further, a study by Khaledian (2013) revealed that there are significant negative correlations between students' self-esteem and their test anxiety. In addition, the cross-sectional study among the medical students during the COVID-19 conducted by Mastour et al. (2021) showed that the level of anxiety among female students is significantly higher than among male students. Moreover, a research study conducted by Arora et al. (2021) among university students was aimed at analyzing the effect of COVID-19 and online education on student's anxiety and self-efficacy. Their findings explained that students' anxiety has a negative effect on their self-efficacy. The results also marked that the students experienced much anxiety because of online examinations in comparison to coronavirus-induced anxiety. It was also found that the relationship between anxiety and self-efficacy was stronger at low levels of coping strategy, whereas it got greatly weakened at high levels of the coping strategy. Moreover, the study of Alsaady et al. (2020) among bachelor level university students was intended to examine the impact of the COVID-19 pandemic on student's exam anxiety and its relationship with other factors. It revealed that both female and male students have high anxiety levels. In addition, no significant correlation between any demographic information and anxiety level was noticed, except the gender: female students have a higher anxiety level than male students.

The current research is consistent with the previous studies, such as Mastour et al. (2021) \& Alsaady et al. (2020), in investigating the level of test anxiety among university students during the COVID-19 crisis. Also, it is 
compatible with the previous study by Park \& Byun (2021) in examining the relationship between test anxiety and self-esteem among university students during the COVID-19 pandemic. However, the current research is different from the previous studies in terms of the sample.

As test anxiety can cause psychological and physiological problems, it is necessary to examine the relationship between test anxiety and self-esteem in order to tackle this problem (Yoon \& Kwon, 2015). Furthermore, the COVID-19 pandemic is an extraordinary conundrum, so it increases the need to shed light on test anxiety and its relationship to self-esteem during the pandemic.

\subsection{Research Hypotheses}

1) The level of test anxiety among the students of the faculty of Science and Arts during the COVID-19 pandemic is high.

2) There is a significant negative correlation between test anxiety and self-esteem among the students of the faculty of Science and Arts during the COVID-19 pandemic.

3) There are significant differences in test anxiety among the students of the faculty of Science and Arts during the COVID-19 pandemic according to gender variable.

\section{Method}

\subsection{Participants}

The population of the research was the students of the faculty of Science and Arts at Northern Border University, Rafha campus, KSA, who were in the second semester of the academic year 2020-2021: $(n=1115)$ students, (352) male and (763) female students.

\subsection{Sample}

After obtaining approval from the authorities of Northern Border University to conduct the research, the data were collected from the $23^{\text {rd }}$ of February to the first of March 2021, i.e., prior to the commencement of the midterm exams of the second semester. The sample of the research consisted of (336) students who responded electronically and they represent (30.13\%) of the research population. The title of the research, confidentiality of the questionnaires, and the objective of collecting the data were stated to the students in the first part of the questionnaire.

Research Sample Description:

Table 1. Sample description according to gender variable

\begin{tabular}{lll}
\hline Gender & Frequency & Percent \\
\hline Males & 91 & 27.1 \\
Females & 245 & 72.9 \\
Total & 336 & 100.0 \\
\hline
\end{tabular}

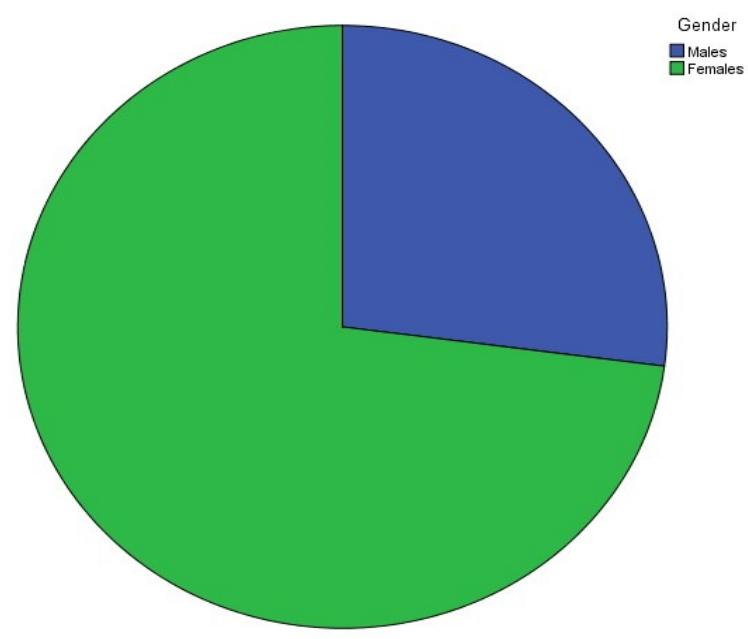

Figure 1. Participants according to gender variable 


\subsection{Research Instruments}

2.3.1 A preliminary data form designed by the researcher to determine the gender of the student.

2.3.2 Westside Test Anxiety Scale by Driscoll (2007)

The researcher used the Scale for the following reasons:

1) The scale has excellent psychometric properties.

2) The scale is a widely-used screening tool for assessing test anxiety in educational settings (Talwar et al., 2019) and it has been used to measure test anxiety among university students.

The scale consists of ten items classified into two main dimensions:

1) Impairment (memory loss and poor cognitive processing) consists of 6 paragraphs, which are 1, 4, 5, 6, 8,10 .

2) Worry (catastrophizing) consists of 4 paragraphs, which are 2, 3, 7, 9.

The total score for the Scale ranges between $10 \& 50$ and the rating is from 1 to 5 .

Psychometric properties for the Scale in the current research

The Scale was translated into the Arabic language by the researcher and then exposed to fourteen faculty members as arbitrators, two of them specialized in the English language in the department of languages and translation; two in the Arabic language and ten in psychology, to ensure that the Arabic translation is identical and consistent with the English version in terms of accuracy and clarity of the items.

\section{A Pilot Study for the Westside Test Anxiety Scale}

To investigate the psychometric properties of the items included in the Westside Test Anxiety Scale, the researcher applied the scale in a pilot study consisted of (48) students selected randomly from the current research population. After scoring the responses, the researcher did the following:

A -Items internal consistency

The researcher applied the Person correlation equation to get correlation coefficients between the scores of each item to the corrected total score of the subscale. The following table shows the results of these computations:

Table 2. Person corrected Item-Total correlation coefficients for items (1, 4, and 5) of the Westside Test Anxiety Scale $(\mathrm{n}=48)$

\begin{tabular}{lll}
\hline \multicolumn{3}{l}{ Impairment (memory loss \& poor cognitive processing) } \\
\hline Item No. & Corrected Item-Total Correlation & Probability (significance) \\
\hline 1 & .551 & .001 \\
4 & .695 & .001 \\
5 & .652 & .001
\end{tabular}

Table 3. Person corrected Item-Total correlation coefficients for items $(6,8$, and 10) of the Westside Test Anxiety Scale $(\mathrm{n}=48)$

\begin{tabular}{lll}
\hline \multicolumn{3}{l}{ Impairment } \\
\hline Item Nom & Corrected Item-Total Correlation & Probability (significance) \\
\hline 6 & .729 & .001 \\
8 & .822 & .001 \\
10 & .516 & .001
\end{tabular}

Table 4. Person corrected Item-Total correlation coefficients for items (2, 3, and 7) of the Westside Test Anxiety Scale $(\mathrm{n}=48)$

\begin{tabular}{lll}
\hline \multicolumn{2}{l}{ Worry (Catastrophe) } & \\
\hline Item No. & Corrected Item-Total Correlation & Probability (significance) \\
\hline 2 & .477 & .001 \\
3 & .677 & .001 \\
7 & .664 & .001 \\
\hline
\end{tabular}


Table 5. Person corrected Item-Total correlation coefficients for the item (9) of the Westside Test Anxiety Scale $(\mathrm{n}=48)$

\begin{tabular}{lll}
\hline \multicolumn{2}{l}{ Worry (Catastrophe) } \\
\hline Item No. & Corrected Item-Total Correlation & Probability (significance) \\
\hline 9 & .589 & .001
\end{tabular}

From Tables (2-5), the researcher notes that the values of all correlation coefficients are positive and significant at the level of (0.001). These results indicate that all items have a high internal consistency with their corrected total scores of the subscale.

\section{B - Reliability Coefficients}

The researcher computed both Cronbach's Alpha and Spearman-Brown Coefficients for each subscale, and the Westside Test Anxiety Scale total scores. The following table explains the results of these computations:

Table 6. Results of Cronbach's Alpha and Spearman-Brown Reliability Coefficients for the Westside Test Anxiety Scale total scores $(n=48)$

\begin{tabular}{llll}
\hline Subscales & No of Items & \multicolumn{2}{l}{ Reliability Coefficients } \\
\cline { 3 - 4 } & & Alpha & Spearman-Brown \\
\hline Impairment total scores & 6 & .864 & .801 \\
Worry total scores & 4 & .786 & .867 \\
Test Anxiety total scores & 10 & .916 & .938 \\
\hline
\end{tabular}

Based on Table 6, the researcher realizes that the values of all reliability coefficients are greater than $(0.785)$. These results mark that all total scores are reliable.

\subsubsection{Self-Esteem Scale by El Sayed (2019)}

The researcher adopted this scale for the following reasons:

1) The scale has excellent psychometric properties and high stability.

2) The scale has been designed and used to measure self-esteem among university students in the KSA.

The scale consists of 14 items and uses the five-point Likert method, whereby the respondent is given an opportunity to determine the degree of his agreement with the item. That is, the respondent's determination is based on the five alternatives ranging from (never apply to $m e=1$, it applies to me perfectly $=5$ ), whereby rating (1) indicates low self-esteem to its lowest levels, whereas appreciation (5) refers to a high level of self-esteem. A higher score on the scale interprets an increased level of self-esteem.

\section{Psychometric properties for the scale in the current research}

To examine the psychometric properties of the items included in the Self-esteem Scale, the researcher applied the scale in a pilot study, consisted of (48) students chosen randomly from the current research population. After scoring the responses, the researcher carried out the following:

A - Items internal consistency

The researcher applied the Person correlation equation to obtain correlation coefficients between the scores of each item to the corrected total score of the Self-esteem Scale. The following table shows the results of these computations:

Table 7. Person corrected Item-Total correlation coefficients for items (1- 6) of the Self-esteem Scale ( $\mathrm{n}=48)$

\begin{tabular}{llllll}
\hline Item No. & $\begin{array}{l}\text { Corrected Item-Total } \\
\text { Correlation }\end{array}$ & $\begin{array}{l}\text { Probability } \\
\text { (significance) }\end{array}$ & Item No. & $\begin{array}{l}\text { Corrected Item-Total } \\
\text { Correlation }\end{array}$ & $\begin{array}{l}\text { Probability } \\
\text { (significance) }\end{array}$ \\
\hline 1 & .386 & .003 & 4 & .318 & .014 \\
2 & .121 & .206 & 5 & .402 & .002 \\
3 & .365 & .006 & 6 & .342 & .008 \\
\hline
\end{tabular}


Table 8. Person corrected Item-Total correlation coefficients for items (7-12) of the Self-esteem Scale $(n=48)$

\begin{tabular}{llllll}
\hline Item No. & $\begin{array}{l}\text { Corrected Item-Total } \\
\text { Correlation }\end{array}$ & $\begin{array}{l}\text { Probability } \\
\text { (significance) }\end{array}$ & Item No. & $\begin{array}{l}\text { Corrected Item-Total } \\
\text { Correlation }\end{array}$ & $\begin{array}{l}\text { Probability } \\
\text { (significance) }\end{array}$ \\
\hline 7 & .635 & .001 & 10 & .474 & .001 \\
8 & .379 & .004 & 11 & .689 & .001 \\
9 & .704 & .001 & 12 & .328 & .012 \\
\hline
\end{tabular}

Table 9. Person corrected Item-Total correlation coefficients for items (13 and 14) of the Self-esteem Scale ( $\mathrm{n}=$ 48)

\begin{tabular}{llllll}
\hline Item No. & $\begin{array}{l}\text { Corrected Item-Total } \\
\text { Correlation }\end{array}$ & $\begin{array}{l}\text { Probability } \\
\text { (significance) }\end{array}$ & Item No. & $\begin{array}{l}\text { Corrected Item-Total } \\
\text { Correlation }\end{array}$ & $\begin{array}{l}\text { Probability } \\
\text { (significance) }\end{array}$ \\
\hline 13 & .252 & .043 & 14 & .056 & .349 \\
\hline
\end{tabular}

From Tables (7-9), the researcher notes that the values of all correlation coefficients are positive and significant at the level of (0.05), except the values of items (2) and (14), and thus the researcher decided to drop them out. Following this decision, the final structure of this scale consists of only (12) items, all of which have good internal consistency with the scale's total score.

B - Reliability Coefficients:

The researcher computed both Cronbach's Alpha and Spearman-Brown Coefficients for the Self-esteem total scores. The following table shows the results of these computations:

Table 10. Results of Cronbach's Alpha and Spearman-Brown Reliability Coefficients for the Self-esteem total scores $(\mathrm{n}=48)$

\begin{tabular}{llll}
\hline Scale & No of Items & \multicolumn{2}{l}{ Reliability Coefficients } \\
\cline { 3 - 4 } & & Alpha & Spearman-Brown \\
\hline Self-esteem total scores & 12 & .796 & .746
\end{tabular}

From Table 10, the researcher notices that the values of reliability coefficients are greater than $(0.745)$. These results point out that the total scores of this scale are reliable.

\subsection{Research Design}

A descriptive approach was adopted because it suits the purpose of the current research, which meant to examine the level of test anxiety and the relationship between test anxiety and self-esteem among college students during the COVID-19 pandemic, as well as identify the differences in test anxiety among the students according to gender variable. Moreover, the descriptive method reflects the data on the phenomenon as it occurs in reality.

\section{Results and Discussion}

\subsection{Results of Hypothesis (1)}

To test hypothesis (1), which states "the level of test anxiety among the students of the faculty of Science and Arts during the COVID-19 pandemic is high", the researcher did the following:

Table 11. Confidence intervals of the means of observed means for test anxiety scores among the students of the faculty of Science and Arts during the COVID-19 pandemic $(\mathrm{n}=336)$

\begin{tabular}{lllll}
\hline \multirow{2}{*}{$\begin{array}{l}\text { Test } \\
\text { subscales }\end{array}$} & anxiety & Mean (SD) & & \multicolumn{2}{l}{$95 \%$ CI of observed means } \\
\cline { 2 - 5 } & Theoretical & Observed & LL & UL \\
\hline Impairment & $18.0(4.00)$ & $21.93(5.62)$ & 21.33 & 22.53 \\
Worry & $12.0(2.67)$ & $15.22(3.86)$ & 14.81 & 15.64 \\
Total scores & $30.0(6.67)$ & $37.15(9.02)$ & 36.19 & 38.12 \\
\hline
\end{tabular}

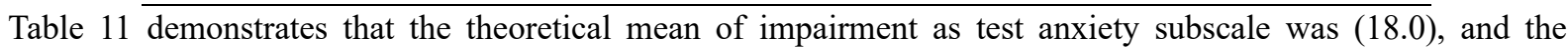
observed mean was (21.93). The theoretical mean for worry as test anxiety subscale was (12.0), and the observed mean was (15.22). The theoretical mean for the total scores of the scale was (30.0), and the observed mean was (37.15). 
Table 12. Results of one sample (t) test to determine the level of test anxiety among the students of the faculty of Science and Arts during the COVID-19 pandemic $(\mathrm{df}=335)$

\begin{tabular}{llllll}
\hline $\begin{array}{l}\text { Test anxiety } \\
\text { subscales }\end{array}$ & Mean (SD) & Test Value & T value & $\begin{array}{l}\text { Sig. } \\
(1 \text {-tailed) }\end{array}$ & $\begin{array}{l}\text { Statistical Inference } \\
\text { (Judgment) }\end{array}$ \\
\hline Impairment & $21.93(5.62)$ & 20.00 & 6.303 & .001 & High \\
Worry & $15.22(3.86)$ & 13.33 & 8.983 & .001 & High \\
Total scores & $37.15(9.02)$ & 33.33 & 7.764 & .001 & High
\end{tabular}

Table 12 explains that all the calculated ( $\mathrm{t}$ ) values for the subscales and the total scores of the test anxiety were positive and statistically significant at the level of $(0.001)$, which indicates that the level of test anxiety among the students of the faculty of Science and Arts during the COVID-19 pandemic is high. These results confirm the first hypothesis of the current research.

Table 13. Confidence intervals for the percentage of test anxiety total scores levels among the students of the faculty of Science and Arts during the COVID-19 pandemic: normal, mild and med

\begin{tabular}{llllll}
\hline Levels of test anxiety & Frequency & Percent & SE of percent & \multicolumn{2}{l}{$95 \%$ CI } \\
\cline { 5 - 6 } & & & & LL & UL \\
\hline Normal (LT 20) & 9 & 2.68 & .0538 & Zero & 13.23 \\
Mild $(20-26)$ & 31 & 9.23 & .0519 & Zero & 19.41 \\
Med $(27-33)$ & 80 & 23.81 & .0476 & 14.48 & 33.14 \\
\hline
\end{tabular}

Table 14. Confidence intervals for the percentage of test anxiety total scores levels among the students of the faculty of Science and Arts during the COVID-19 pandemic: high and severe

\begin{tabular}{llllll}
\hline Levels of test anxiety & Frequency & Percent & SE of percent & \multicolumn{2}{l}{$95 \% \mathrm{CI}$} \\
\cline { 5 - 6 } & & & & LL & UL \\
\hline High (34 - 40) & 84 & 25.00 & .0472 & 15.74 & 34.26 \\
Severe (GT 40) & 132 & 39.29 & .0425 & 30.95 & 47.62 \\
\hline
\end{tabular}

Tables (13 and 14) display that, in terms of levels of test anxiety, there are (9) (2.68\%) participants who reported a normal level of test anxiety, whereas (31) (9.23\%) participants showed a mild level of test anxiety. Also, (80) (23.81\%) respondents reported a medium level of test anxiety, while (84) (25.00\%) participants revealed a high level of test anxiety. Finally, there are (132) (39.29\%) respondents who reported a severe level of test anxiety. These results show that more than three-fifths, exactly (64.29\%), of the research sample had reported high and severe levels of test anxiety, which ensuring the previous results of the first hypothesis.

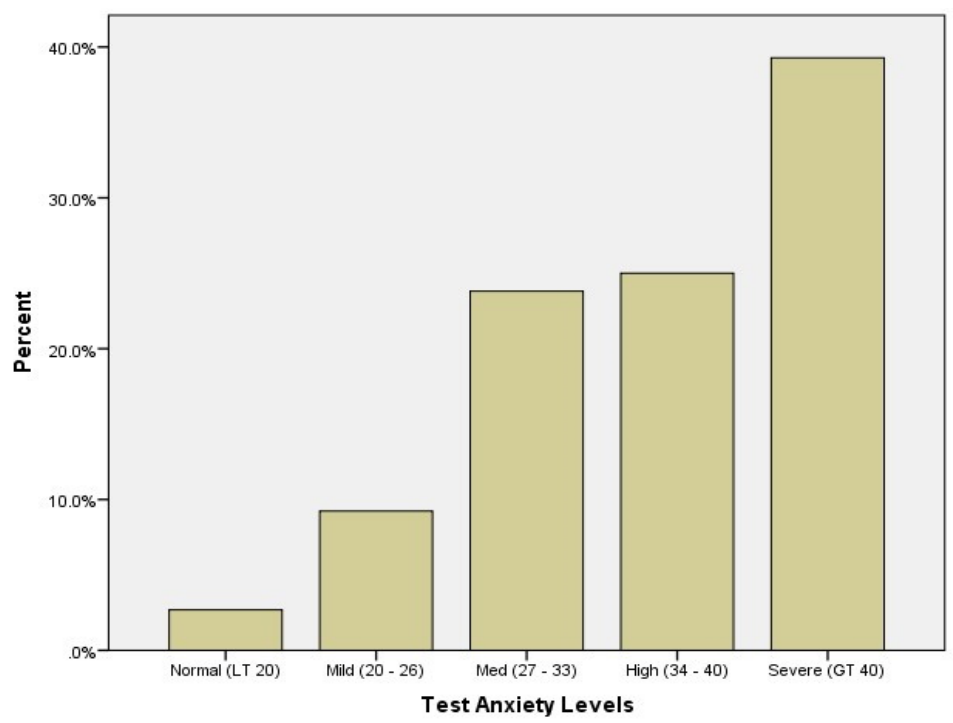

Figure 2. Percent Bars of test anxiety total scores' levels among the participants 
Furthermore, from figure (2), the percentage of the students who reported high and severe levels of test anxiety is greater than the percentage of the students in the other levels of test anxiety. The current research explored the level of test anxiety during the COVID-19 pandemic and its results were aligned with the findings of a previous study carried out by Alsaady et al. (2020). However, a study by Arora et al. (2021) marked that the students reported more anxiety due to online examinations in comparison to coronavirus-induced anxiety.

The main concerns which correlate to anxiety and stress among college students are academic performance, pressure to succeed, and post-graduation plans (Beiter et al., 2015). Moreover, owing to the COVID -19, the higher education institutions were forced to change their entire instructional system to online. Although it allows learners to study from home, it hinders the delivery of interactive, face-to-face, personalized experience-based learning in lively campus life (Arora, 2021). However, during the COVID-19 pandemic, learners have different psychosocial responses (Sugiyanto et al., 2020). For example, test anxiety could be one of several variables which have a potential effect on the exam score (Mohamadi \& Soleimani, 2014). Considering these arguments, the researcher believes that much attention should be paid to the level of test anxiety during the COVID-19 pandemic.

\subsection{Results of Hypothesis (2)}

To test hypothesis (2), which states " there is a significant negative correlation between test anxiety and self-esteem among the students of the faculty of Science and Arts during the COVID-19 pandemic", the researcher did the following:

Table 15. Results of Pearson Correlation coefficients to explain the significance of the relationship between test anxiety and self-esteem among the students of the faculty of Science and Arts during the COVID-19 pandemic $(\mathrm{n}=336)$

\begin{tabular}{llll}
\hline Test anxiety subscales & Correlation coefficients & Sig. (1-tailed) & Statistical Inference \\
\hline Impairment & -.062 & .129 & There isn't a sig. correlation \\
Worry & -.135 & .007 & There is a negative correlation \\
Total scores & -.096 & .039 & There is a negative correlation \\
\hline
\end{tabular}

From Table 15, it becomes clear that the sign of the value of the correlation coefficient between the impairment subscale and self-esteem is negative but statistically insignificant. On the other hand, the values of the correlation coefficients between both worry subscale and test anxiety total scores with self-esteem are negative signs, and both are statistically significant, which illustrates that there was a negative correlation between both worry subscale and test anxiety total scores with self-esteem. These results partially confirm the second hypothesis of this research.

To explore the significance of differences between different categories of the students according to their self-esteem scores, the researcher classified those students into four categories (low, med, high, and extremely high), and applied a one-way analysis of variance. The following tables represent the results of these procedures.

Table 16. Frequencies and percent of self-esteem total scores levels among the students of the faculty of Science and Arts during the COVID-19 pandemic: low, med and high

\begin{tabular}{lll}
\hline Levels of self-esteem & Frequency & Percent \\
\hline Low (LT 32) & 19 & 5.7 \\
Med (32 - 40) & 76 & 22.6 \\
High (41 - 48) & 92 & 27.4
\end{tabular}

Table 17. Frequencies and percent of self-esteem total scores levels among the students of the faculty of Science and Arts during the COVID-19 pandemic: extremely high

\begin{tabular}{lll}
\hline Levels of self-esteem & Frequency & Percent \\
\hline Extremely High (GT 48) & 149 & 44.3 \\
\hline
\end{tabular}

Tables (16 and 17) explain that there were (19) (5.7\%) participants, who showed a low level of self-esteem, while (76) $(22.6 \%)$ participants reported a medium level of self-esteem. Furthermore, the participants who revealed high and extremely high levels of self-esteem were $(92)(27.4 \%)$ and (149) $(44.3 \%)$ respectively. It is obvious that more than two-third, exactly (71.7\%), of the research participants, reported high and extremely high levels of self-esteem. 
Table 18. ANOVA for test anxiety among the students of the faculty of Science and Arts during the COVID-19 pandemic according to the levels of self-esteem: impairment

\begin{tabular}{llllllll}
\hline Test anxiety & Source of variance & Sum of Squares & Df & Mean Square & F & Sig. & Statistical Inference \\
\hline Impairment & Between Gs & 334.278 & 3 & 111.426 & 3.614 & .014 & The four groups' \\
& Within Gs & 10235.148 & 332 & 30.829 & & & means are not equal \\
& Total & 10569.426 & 335 & & & & \\
\hline
\end{tabular}

Table 19. ANOVA for test anxiety among the students of the faculty of Science and Arts during the COVID-19 pandemic according to the levels of self-esteem: worry

\begin{tabular}{llllllll}
\hline Test anxiety & Source of variance & Sum of Squares & Df & Mean Square & F & Sig. & Statistical Inference \\
\hline Worry & Between Gs & 185.767 & 3 & 61.922 & 4.284 & .006 & The four groups' \\
& Within Gs & 4798.492 & 332 & 14.453 & & & means are not equal \\
& Total & 4984.259 & 335 & & & & \\
\hline
\end{tabular}

Table 20. ANOVA for test anxiety among the students of the faculty of Science and Arts during the COVID-19 pandemic according to the levels of self-esteem: total scores

\begin{tabular}{|c|c|c|c|c|c|c|c|}
\hline Test anxiety & $\begin{array}{l}\text { Source } \\
\text { variance }\end{array}$ & $\begin{array}{l}\text { Sum of } \\
\text { Squares }\end{array}$ & Df & $\begin{array}{l}\text { Mean } \\
\text { Square }\end{array}$ & $\mathrm{F}$ & Sig. & $\begin{array}{l}\text { Statistical } \\
\text { Inference }\end{array}$ \\
\hline \multirow[t]{3}{*}{ Total scores } & Between Gs & 995.711 & 3 & 331.904 & \multirow[t]{3}{*}{4.194} & \multirow[t]{3}{*}{.006} & \multirow{3}{*}{$\begin{array}{l}\text { The four } \\
\text { groups' means } \\
\text { are not equal }\end{array}$} \\
\hline & Within Gs & 26274.242 & 332 & 79.139 & & & \\
\hline & Total & 27269.952 & 335 & & & & \\
\hline
\end{tabular}

Tables (18-20) explain that the means of the two subscales and total scores of the test anxiety for the four groups of levels of self-esteem were not equal, which indicates the existence of significant differences. To explore the positions of these significant differences, the researcher applied the Duncan test, which explains the following results:

Table 21. Duncan test results for test anxiety means among the students of the faculty of Science and Arts during the COVID-19 pandemic, according to levels of self-esteem: high and extremely high

\begin{tabular}{|c|c|c|c|}
\hline \multirow[t]{3}{*}{ Levels of self-esteem total scores } & \multicolumn{3}{|c|}{ Subset for alpha $=0.05$} \\
\hline & Impairment & Worry & Total Test Anxiety \\
\hline & 2 & 1 & 1 \\
\hline High & 20.68 & 14.51 & 35.19 \\
\hline Extremely high & 22.01 & 15.03 & 37.04 \\
\hline
\end{tabular}

Table 22. Duncan test results for test anxiety means among the students of the faculty of Science and Arts during the COVID-19 pandemic, according to levels of self-esteem: med and low

\begin{tabular}{|c|c|c|c|c|c|c|}
\hline \multirow{3}{*}{$\begin{array}{l}\text { Levels of self-esteem } \\
\text { total scores }\end{array}$} & \multicolumn{6}{|c|}{ Subset for alpha $=0.05$} \\
\hline & \multicolumn{2}{|c|}{ Impairment } & \multicolumn{2}{|l|}{ Worry } & \multicolumn{2}{|c|}{ Total Test Anxiety } \\
\hline & 1 & 2 & 1 & 2 & 1 & 2 \\
\hline Med & 22.55 & & 15.88 & & 38.43 & \\
\hline Low & & 24.84 & & 17.52 & & 42.37 \\
\hline
\end{tabular}

From Tables (21 and 22), the researcher notes that the means of the students at the low level of self-esteem was the greatest: they were (24.84), (17.52), (42.37) for impairment, worry, and the total test anxiety respectively; compared to the other levels of self-esteem. It is obvious that the values of the means of total test anxiety scores are increasing gradually with decreasing of levels of self-esteem total scores, which confirm the negative correlation between these two variables, therefore, ensuring the results of the second hypothesis. These results are compatible with the results of the previous studies by Park \& Byun (2021) and Khaledian (2013). However, the study conducted by Nugroho et al. (2021) which aimed to investigate the effectiveness of the solution-focused brief counseling approach to develop self-esteem for high school students for the 2020/2021 academic year, shows that the solution-focused brief counseling approach is effective for developing students' self-esteem. Relatively, Liu et al. (2006) argue that "Test anxiety should be related to the personality and self-esteem", and a research 
study conducted by Akinleke (2012) revealed that low anxiety students experienced higher GPAs than high anxiety students, and there was a positive relationship between self-esteem and academic performance. Therefore, the researcher thinks that higher education institutions and all concerned bodies should keep an eye on the mental health of the students during the COVID-19.

\subsection{Results of Hypothesis (3)}

To test hypothesis (3), which states " There are significant differences in test anxiety among the students of the faculty of Science and Arts during the COVID-19 pandemic according to gender variable", the researcher did the following:

Table 23 Results of two independent samples T-Test to explain the significance of differences in test anxiety among the students of the faculty of Science and Arts during the COVID-19 pandemic according to gender variable: impairment

\begin{tabular}{lllllllll}
\hline $\begin{array}{l}\text { Test anxiety } \\
\text { subscales }\end{array}$ & $\begin{array}{l}\text { Gender } \\
\text { Groups }\end{array}$ & Mean & SD & T value & df & P. & Statistical Inference & \\
\hline Impairment & Males & 23.33 & 6.23 & 2.608 & 141 & .005 & $\begin{array}{l}\text { The difference is Sig. } \\
\text { males' mean is greater }\end{array}$ \\
& Females & 21.41 & 5.29 & & & & & \\
& Females & 36.54 & 8.53 & & & & &
\end{tabular}

Table 24 Results of two independent samples T-Test to explain the significance of differences in test anxiety among the students of the faculty of Science and Arts during the COVID-19 pandemic according to gender variable: worry

\begin{tabular}{llllllllll}
\hline $\begin{array}{l}\text { Test anxiety } \\
\text { subscales }\end{array}$ & $\begin{array}{l}\text { Gender } \\
\text { Groups }\end{array}$ & Mean & SD & T value & df & P. & Statistical Inference & \\
\hline Worry & Males & 15.48 & 4.15 & .753 & 334 & .226 & $\begin{array}{l}\text { The difference } \\
\text { significant }\end{array}$ & is not \\
& Females & 15.13 & 3.75 & & & & & \\
\hline
\end{tabular}

Table 25 . Results of two independent samples T-Test to explain the significance of differences in test anxiety among the students of the faculty of Science and Arts during the COVID-19 pandemic according to gender variable: total scores

\begin{tabular}{lllllllll}
\hline $\begin{array}{l}\text { Test anxiety } \\
\text { subscales }\end{array}$ & $\begin{array}{l}\text { Gender } \\
\text { Groups }\end{array}$ & Mean & SD & T value & df & P. & Statistical Inference & \\
\hline Total scores & Males & 38.81 & 10.09 & 1.911 & 141 & .029 & $\begin{array}{l}\text { The difference is Sig. } \\
\text { males' mean is greater }\end{array}$ \\
& Females & 36.54 & 8.53 & & & &
\end{tabular}

Tables (23-25) demonstrate that the P-value of the impairment subscale was (0.005), which shows that the difference between the two means is statistically significant, and the males' mean was greater. While the P-value for the worry subscale was $(0.226)$, which indicates that the difference was insignificant, the P-value of the test anxiety total scores was (0.029), which discloses that the difference between the two means is statistically significant, and the males' mean is greater.

Table 26. Results of Mann-Whitney Test to explain the significance of differences in test anxiety among the students of the faculty of Science and Arts during the COVID-19 pandemic according to gender variable: impairment

\begin{tabular}{llllllll}
\hline $\begin{array}{l}\text { Test anxiety } \\
\text { subscales }\end{array}$ & $\begin{array}{l}\text { Gender } \\
\text { Groups }\end{array}$ & Mean of ranks & U Value & Z Value & P. & Statistical Inference & \\
\hline Impairment & Males & 195.54 & 8687 & -3.117 & .001 & $\begin{array}{l}\text { The difference is Sig. } \\
\text { males' mean is greater }\end{array}$ \\
\cline { 2 - 4 } & Females & 158.46 & & & & \\
\hline
\end{tabular}

Table 27. Results of Mann-Whitney Test to explain the significance of differences in test anxiety among the students of the faculty of Science and Arts during the COVID-19 pandemic according to gender variable: worry

\begin{tabular}{llllllll}
\hline $\begin{array}{l}\text { Test anxiety } \\
\text { subscales }\end{array}$ & $\begin{array}{l}\text { Gender } \\
\text { Groups }\end{array}$ & $\begin{array}{l}\text { Mean of } \\
\text { ranks }\end{array}$ & U Value & Z Value & P. & Statistical Inference & \\
\hline Worry & Males & 178.03 & 10280 & -1.103 & .135 & $\begin{array}{l}\text { The difference } \\
\text { insignificant }\end{array}$ & is \\
& Females & 164.96 & & & & & \\
\hline
\end{tabular}


Table 28. Results of Mann-Whitney Test to explain the significance of differences in test anxiety among the students of the faculty of Science and Arts during the COVID-19 pandemic according to gender variable: total scores

\begin{tabular}{llllllll}
\hline $\begin{array}{l}\text { Test anxiety } \\
\text { subscales }\end{array}$ & $\begin{array}{l}\text { Gender } \\
\text { Groups }\end{array}$ & $\begin{array}{l}\text { Mean of } \\
\text { ranks }\end{array}$ & & U Value & Z Value & P. & Statistical Inference \\
\hline Total scores & Males & 189.35 & 9250 & -2.401 & .008 & $\begin{array}{l}\text { The difference is Sig. } \\
\text { males' mean is greater }\end{array}$
\end{tabular}

It is observed from Tables (26-28) that the $\mathrm{Z}$ value of the impairment subscale was statistically significant, and this confirms the existence of differences, and the males' mean was greater. While the $Z$ value of the worry subscale was insignificant, which means there were no differences, the $Z$ value for the test anxiety total scores was statistically significant, which points out that the differences and the males' mean were greater. These results confirm the previous results of the ( $\mathrm{t}$ ) test.

Table 29. MANOVA for test anxiety among the students of the faculty of Science and Arts during the COVID-19 pandemic, according to gender variable

\begin{tabular}{|c|c|c|c|c|c|c|c|}
\hline $\begin{array}{l}\text { Source of } \\
\text { variance }\end{array}$ & Test anxiety & $\begin{array}{l}\text { Sum } \\
\text { Squares }\end{array}$ & $\overline{\mathrm{Df}}$ & $\begin{array}{l}\text { Mean } \\
\text { Square }\end{array}$ & $\mathrm{F}$ & Sig. & Statistical Inference \\
\hline \multirow{3}{*}{ Gender $(\mathrm{G})$} & Impairment & 220.972 & 1 & 220.972 & 7.299 & .007 & The difference is Sig. \\
\hline & Worry & 7.386 & 1 & 7.386 & .507 & .477 & The difference is not Sig. \\
\hline & Total & 309.156 & 1 & 309.156 & 3.928 & .048 & The difference is Sig. \\
\hline
\end{tabular}

Table 30. MANOVA for test anxiety among the students of the faculty of Science and Arts during the COVID-19 pandemic, according to levels of self-esteem

\begin{tabular}{llllllll}
\hline $\begin{array}{l}\text { Source of } \\
\text { variance }\end{array}$ & Test anxiety & $\begin{array}{l}\text { Sum of } \\
\text { Squares }\end{array}$ & Df & $\begin{array}{l}\text { Mean } \\
\text { Square }\end{array}$ & F & Sig. & Statistical Inference \\
\hline Self- & Impairment & 245.205 & 3 & 81.735 & 2.700 & .046 & The difference is Sig. \\
Esteem & Worry & 127.271 & 3 & 42.424 & 2.910 & .035 & The difference is Sig. \\
Levels & Total & 718.615 & 3 & 239.538 & 3.044 & .029 & The difference is Sig. \\
\hline
\end{tabular}

Table 31. MANOVA for test anxiety among the students of the faculty of Science and Arts during the COVID-19 Pandemic, according to gender variable and levels of self-esteem: interaction $\left(\mathrm{G}^{*} \mathrm{SEL}\right)$

\begin{tabular}{llllllll}
\hline $\begin{array}{l}\text { Source of } \\
\text { variance }\end{array}$ & Test anxiety & $\begin{array}{l}\text { Sum of } \\
\text { Squares }\end{array}$ & Df & $\begin{array}{l}\text { Mean } \\
\text { Square }\end{array}$ & F & Sig. & Statistical Inference \\
\hline \multirow{2}{*}{$\begin{array}{l}\text { Interaction } \\
\left(\mathrm{G}^{*} \mathrm{SEL}\right)\end{array}$} & Impairment & 62.181 & 3 & 20.727 & .685 & .562 & The interaction is not Sig. \\
& Worry & 6.613 & 3 & 2.204 & .151 & .929 & The interaction is not Sig. \\
& Total & 104.383 & 3 & 34.794 & .442 & .723 & The interaction is not Sig. \\
\hline
\end{tabular}

Table 32. MANOVA for test anxiety among the students of the faculty of Science and Arts during the COVID-19 pandemic, according to gender variable and levels of self-esteem: error

\begin{tabular}{llllllll}
\hline $\begin{array}{l}\text { Source of } \\
\text { variance }\end{array}$ & Test anxiety & $\begin{array}{l}\text { Sum of } \\
\text { Squares }\end{array}$ & Df & Mean Square & F & Sig. & Statistical Inference \\
\hline \multirow{3}{*}{ Error } & Impairment & 9930.010 & 328 & 30.274 & & & \\
& Worry & 4781.243 & 328 & 14.577 & & & \\
& Total & 25814.596 & 328 & 78.703 & & & \\
\hline
\end{tabular}

Table 33. MANOVA for test anxiety among the students of the faculty of Science and Arts during the COVID-19 pandemic, according to gender variable and levels of self-esteem: corrected total

\begin{tabular}{|c|c|c|c|c|c|c|}
\hline $\begin{array}{l}\text { Source of } \\
\text { variance }\end{array}$ & Test anxiety & $\begin{array}{l}\text { Sum of } \\
\text { Squares }\end{array}$ & $\mathrm{Df}$ & $\begin{array}{lr}\text { Mean } & F \\
\text { Square } & \end{array}$ & Sig. & Statistical Inference \\
\hline \multirow{3}{*}{$\begin{array}{l}\text { Corrected } \\
\text { Total }\end{array}$} & Impairment & 10569.426 & 335 & & & \\
\hline & Worry & 4984.259 & 335 & & & \\
\hline & Total & 27269.952 & 335 & & & \\
\hline
\end{tabular}


Tables (29-33) indicate that there were significant differences in test anxiety subscales and total scores according to self-esteems levels. According to students' gender, the differences were significant only in impairment subscale and test anxiety total scores. All interactions between students' gender and self-esteem levels on test anxiety subscales and total scores were insignificant.

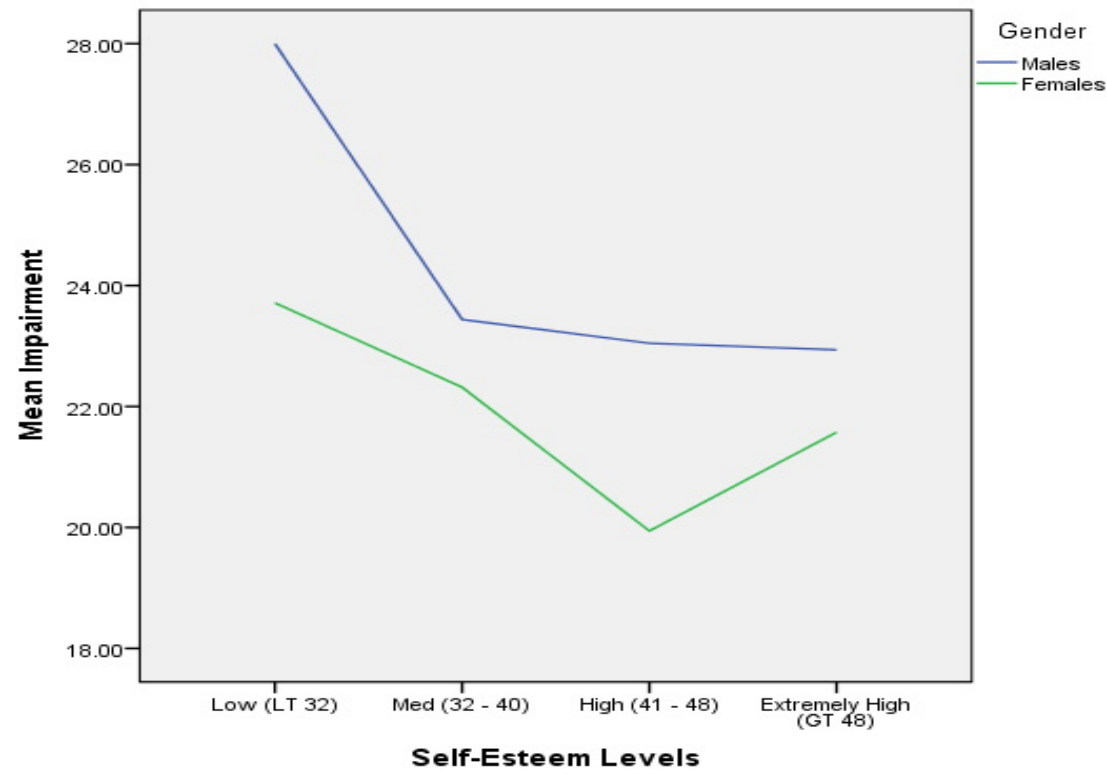

Figure 3. Absence of the interaction between students' gender \& self-esteem levels on the impairment subscale among the participants

As shown in figure (3), the means for the male students was greater than the means for the female students at all levels of self-esteem.

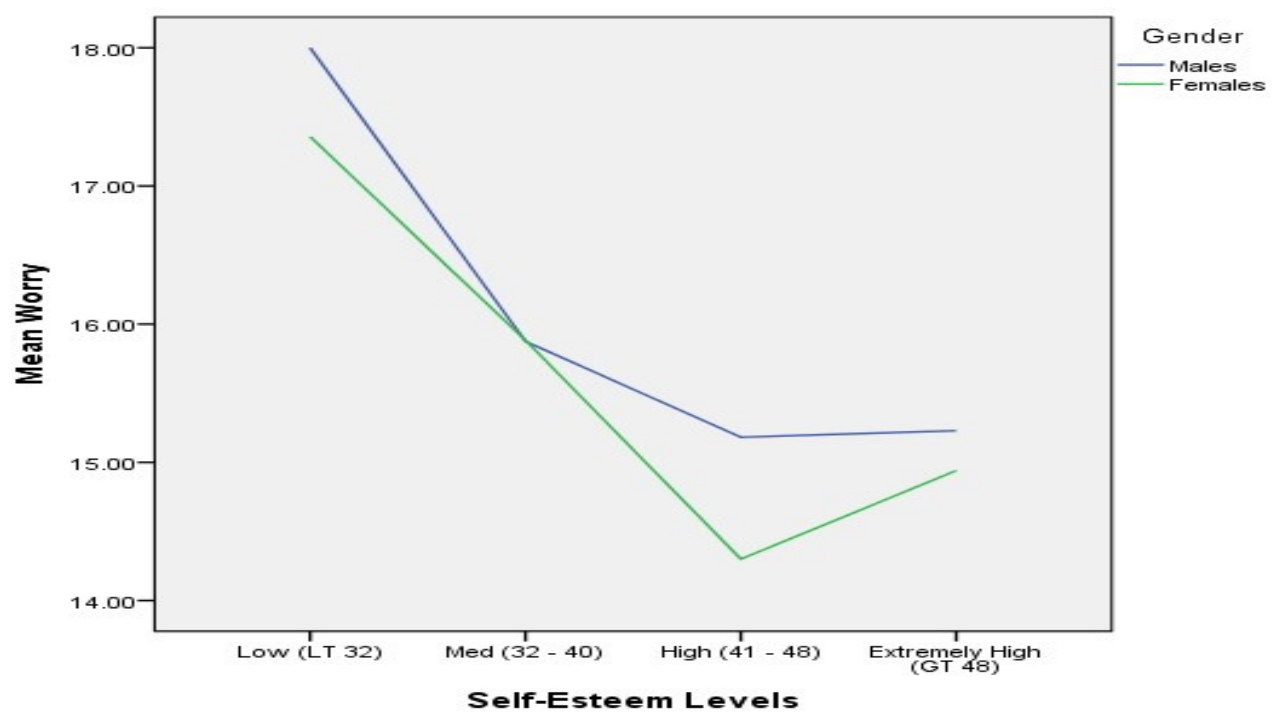

Figure 4. Absence of the interaction between students' gender \& self -esteem levels on the worry subscale among the participants

It is clear from figure (4) that, in terms of worry, the means for both male and female students at a med level of self-esteem have the same value, whereas the males' means at the other levels of self the esteem were not too greater than the females' means at the corresponding levels of the self-esteem. 


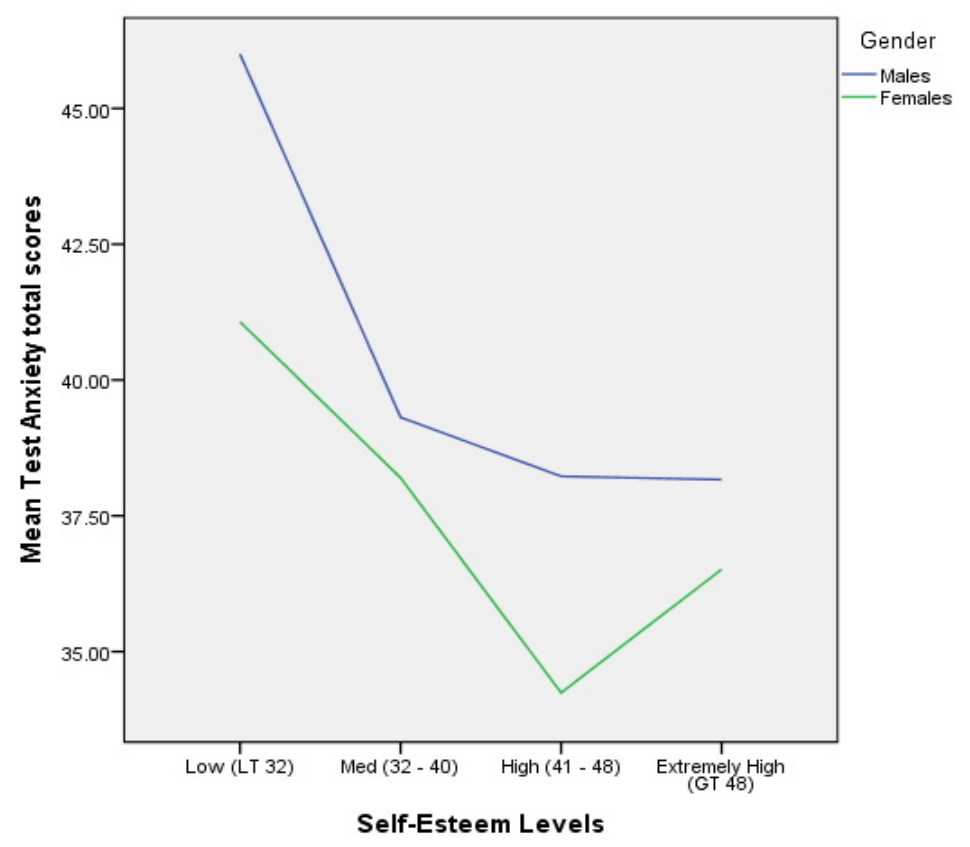

Figure 5. Absence of the interaction between students' gender \& self-esteem levels on the test anxiety total scores among the participants

Figure (5) confirms that the means of test anxiety total scores for males were greater than females at all levels of self-esteem.

The results of the current research are consistent with the results of the previous study aimed to investigate test anxiety among university students (Ojediran \& Oludipe, 2016). Other studies have shown that females have a higher anxiety level than males (Mastour et al., 2021; Alsaady et al., 2020; Rezazadeh, 2009). Moreover, the previous study carried out by Onyeizugbo (2010) among university students indicated that gender was an insignificant predictor of test anxiety. The researcher believes that this contradiction indicates that further research studies are needed.

Finally, stress during education has a negative effect on cognitive functioning and learning and can cause mental distress (Khan et al., 2006), so more investigations are needed to determine the most vulnerable group in order to focus on it.

\section{Conclusion}

The current research attempted to explore the impact of the COVID-19 pandemic on the mental health of the students. In other words, the main objective of the research was to examine the level of test anxiety and the relationship between test anxiety and self-esteem among the students during the COVID-19 pandemic and also identify the differences in test anxiety among the students according to gender variable. To achieve the aims of the research, the descriptive method was used, and data were collected electronically. Results revealed that the level of test anxiety among the students during the COVID-19 pandemic was high. The correlation coefficient between the impairment subscale and self-esteem was negative but statistically insignificant. The findings also confirmed that the correlation coefficients between both worry subscale and test anxiety total scores with self-esteem have resulted in a negative sign, and both are statistically significant. There were significant differences in test anxiety among the students in the impairment subscale, and the males' mean was greater. While there were no significant differences in the worry subscale, there were significant differences in test anxiety total scores, and the males' mean was greater.

General speaking, besides self-esteem, there could be other risk factors standing behind the level of test anxiety during the COVID-19 pandemic. Thus, more efforts and research studies are needed to save the students' mental health and well-being and limit the negative effects of the COVID-19 pandemic on their performance.

\section{Recommendations}

In accordance with the research findings, the following recommendations have been made:

1) Providing psychological counseling programs online for the students during the pandemic. 
2) Implementing online training courses for the students to support them psychologically and protect them in order to reduce anxiety.

3) Developing plans and strategies to enhance the mental health of university students and eradicate the negative effects of the COVID-19 pandemic.

4) Further research studies must be conducted to determine the risk factors and predictable variables of test anxiety during the COVID-19 pandemic, so as to focus firmly on the vulnerable group.

Based on the research results, the researcher proposes the following suggestions:

1) Conducting a research study to investigate the level of test anxiety among high academic achievements students during the COVID-19 pandemic.

2) Researching to examine the relationship between test anxiety and future anxiety among university students during the COVID-19 pandemic.

3) Conducting a research study to explore the relationship between test anxiety and academic variables (academic achievements and the level of study) among university students during the COVID-19 pandemic.

4) Carrying out a research study to examine the level of test anxiety among university students during the COVID-19 pandemic: a comparative study between the students affected with the virus and unaffected ones.

5) Conducting a research study to find out university students' attitudes towards studying via virtual classes.

\section{References}

Akinleke, W. O. (2012). An investigation of the relationship between test anxiety, self esteem and academic performance among polytechnic students in Nigeria. International Journal of Computer Applications, 51(1), 47-50. https://doi.org/10.5120/8010-1376

Alqudah, M. A., \& Rashid, R. A. (2020). A review of factors causing test anxiety. Journal of Qualitative Social Sciences, 2(1), 1-6. Retrieved from https://asianscholarsnetwork.org/journals/index.php/jqss/article/view/42/39

Alsaady, I., Gattan, H., Zawawi, A., Alghanmi, M., \& Zakai, H. (2020). Impact of COVID-19 Crisis on Exam Anxiety Levels among Bachelor Level University Students. Mediterranean Journal of Social Sciences, 11(5), 33. https://doi.org/10.36941/mjss-2020-0052

Arora, S., Chaudhary, P., \& Singh, R. K. (2021). Impact of coronavirus and online exam anxiety on self-efficacy: the moderating role of coping strategy. Interactive Technology and Smart Education, 18(3), 475-492. https://doi.org/10.1108/ITSE-08-2020-0158

Arshad, M., Zaidi, S. M. I. H., \& Mahmood, K. (2015). Self-Esteem \& Academic Performance among University Students. Journal of Education and Practice, 6(1), 156-162.

Asghari, A., Kadir, R. A., Elias, H., \& Baba, M. (2012). Test anxiety and its related concepts: A brief review. Education Sciences and Psychology, (3), 3-8.

Beiter, R., Nash, R., McCrady, M., Rhoades, D., Linscomb, M., Clarahan, M., \& Sammut, S. (2015). The prevalence and correlates of depression, anxiety, and stress in a sample of college students. Journal of Affective Disorders, 173, 90-96. https://doi.org/10.1016/j.jad.2014.10.054

Branden, N. (1990). What Is Self-Esteem? Retrieved from https://eric.ed.gov/?id=ED325783

Cheema, G. K., \& Bhardwaj, M. M. (2021). Study of self-esteem and academic achievement in relation to home environment among adolescents. European Journal of Molecular \& Clinical Medicine, 8(1), 1978-1987.

Driscoll, R. (2007). Westside Test Anxiety Scale Validation. Online submission.

Effiom, B. E., \& Bassey, B. A. (2018). Test anxiety, self-esteem and academic performance among secondary school students in Cross River State, Nigeria. International Journal of Education and Evaluation, 4(9), $18-27$.

El Sayed, W. E. H. (2019). Quality of University Life as a Mediator between Psychological Alienation and Self-Esteem among Students of King Saud University. International Journal of Educational \& Psychological Studies, 5(2), 144-160. https://doi.org/10.31559/EPS2019.5.2.4 
Elgendy, A. A. H. (2020). A teaching strategy to reduce test anxiety. Journal of Organizational Behavior Research, 5(2), 82-98.

Fathi-Ashtiani, A., Ejei, J., Khodapanahi, M. K., \& Tarkhorani, H. (2007). Relationship between self-concept, self-esteem, anxiety, depression and academic achievement in adolescents. Journal of Applied Sciences, 7(7), 955-1000. https://doi.org/10.3923/jas.2007.995.1000

Hashmat, S., Hashmat, M., Amanullah, F., \& Aziz, S. (2008). Factors causing exam anxiety in medical students. Journal-Pakistan Medical Association, 58(4), 167. Retrieved from https://www.jpma.org.pk/PdfDownload/1364

Iliyasu, T., \& Abiodun, J. (2020). Ethical Issues in the Management of Examination in Tertiary Institutions: Review of Literature.

Irawati, N., \& Hajat, N. (2012). Hubungan Antara Harga Diri (Self Esteem) Dengan Prestasi Belajar Pada Siswa Smkn 48 Di Jakarta Timur. Jurnal Ilmiah Econosains, 10(2), 193-210. https://doi.org/10.21009/econosains.0102.04

Javanbakht, N., \& Hadian, M. (2014). The effects of test anxiety on learners' reading test performance. Procedia-Social and Behavioral Sciences, 98, 775-783. https://doi.org/10.1016/j.sbspro.2014.03.481

Jena, P. K. (2020). Impact of Covid-19 on higher education in India. International Journal of Advanced Education and Research (IJAER), 5. https://doi.org/10.31235/osf.io/jg8fr

Jung, S., Kneer, J., \& Krüger, T. H. (2020). Mental health, sense of coherence, and interpersonal violence during the COVID-19 pandemic lockdown in Germany. Journal of clinical medicine, 9(11), 3708. https://doi.org/10.3390/jcm9113708

Khaledian, M. (2013). The relationship between Emotional Intelligence (EQ) with self-esteem and test anxiety and also their academic achievements. Psychology and Social Behavioral Research, 1(1), 1-8. https://doi.org/10.12966/psbr.04.01.2013

Khan, E. A., Munir, H., Afzal, A., \& Ansari, M. M. (2021). Influence of Test Anxiety on Students' Academic Achievement at Secondary Level. Ilkogretim Online, 20(2). https://doi.org/10.17051/ilkonline.2020.02.31

Khan, M. S., Mahmood, S., Badshah, A., Ali, S. U., \& Jamal, Y. (2006). Prevalence of depression, anxiety and their associated factors among medical students in Karachi, Pakistan. Journal-Pakistan Medical Association, 56(12), 583. Retrieved from https://www.jpma.org.pk/PdfDownload/959

Kharsah, W. S., \& Fatmawati, L. (2016). The correlation between levels of self-esteem, university commitment and academic performance among undergraduate students. In Proceedings of the National Conference for Postgraduate Research, Universiti Malaysia Pahang, Pekan, September 24 (Vol. 25, pp. 200-205). Retrieved from https://umpir.ump.edu.my/id/eprint/15073/1/P030\%20pg200-205.pdf

Khoshaim, H. B., Al-Sukayt, A., Chinna, K., Nurunnabi, M., Sundarasen, S., Kamaludin, K., Baloch, G. M., \& Hossain, S. F. A. (2020). Anxiety level of University students during COVID-19 in Saudi Arabia. Frontiers in Psychiatry, 11, 1397. https://doi.org/10.3389/fpsyt.2020.579750

Liu, J. T., Meng, X. P., \& Xu, Q. Z. (2006). The relationship between test anxiety and personality, self-esteem in grade one senior high students. Zhonghua yu Fang yi xue za zhi [Chinese Journal of Preventive Medicine], 40(1), 50-52. Retrieved from https://europepmc.org/article/med/16620604

Mastour, H., Ghalibaf, A. M., \& Niroumand, S. (2021). Remote Online Exams Anxiety during the COVID-19 Crisis: A Cross-Sectional Study among Medical Students. https://doi.org/10.21203/rs.3.rs-144112/v1

Mohamadi, M., Alishahi, Z., \& Soleimani, N. (2014). A study on test anxiety and its relationship to test score and self-actualization of academic EFL students in Iran. Procedia-Social and Behavioral Sciences, 98, 1156-1164. https://doi.org/10.1016/j.sbspro.2014.03.529

Ndirangu, G. W., Muola, J. M., Kithuka, M. R., \& Nassiuma, D. K. (2009). An investigation of the relationship between test anxiety and academic performance in secondary schools in Nyeri District, Kenya. Global journal of educational research, 8(1-2). https://doi.org/10.4314/gjedr.v8i1-2.53761

Neemati, N., Hooshangi, R., \& Shurideh, A. (2014). An Investigation into the Learners' Attitudes towards Factors Affecting their Exam Performance: A Case from Razi University. Procedia - Soc Behav Sci., 98. 1331-1339. https://doi.org/10.1016/j.sbspro.2014.03.550 
Nugroho, A. R., Guswantoro, T., Gunawan, R., Lumbantobing, S. S., \& Murniarti, E. (2021). Developing Junior High School Self-Esteem through the Solution Focused Brief Counseling Approach during the Covid-19 Pandemic. Degres, 20(2), 1-10.

Ojediran, I. A., \& Oludipe, D. I. (2016). Impact of test anxiety and gender on academic performance of Nigerian pre-service science teachers. Journal of Emerging Trends in Educational Research and Policy Studies, 7(3), 247-254. Retrieved from https://hdl.handle.net/10520/EJC196809

Onyeizugbo, E. U. (2010). Self-efficacy, gender and trait anxiety as moderators of test anxiety. Electronic Journal of Research in Educational Psychology, 8(1), 299-312.

Orth, U., \& Robins, R. W. (2014). The development of self-esteem. Current directions in psychological science, 23(5), 381-387. ttps://doi.org/10.1177/0963721414547414

Park, H. J., \& Byun, E. K. (2021). Effect of perceived stress, self esteem, major satisfaction on the test anxiety of nursing students. The Journal of the Convergence on Culture Technology, 7(1), 194-201.

Rezazadeh, M., \& Tavakoli, M. (2009). Investigating the Relationship among Test Anxiety, Gender, Academic Achievement and Years of Study: A Case of Iranian EFL University Students. English Language Teaching, 2(4), 68-74. https://doi.org/10.5539/elt.v2n4p68

Sarason, I. G., \& Sarason, B. R. (1990). Test Anxiety. In Leitenberg H. (Ed.), Handbook of Social and Evaluation Anxiety. Springer, Boston, MA. https://doi.org/10.1007/978-1-4899-2504-6_16

Sarı, S. A., Bilek, G., \& Çelik, E. (2018). Test anxiety and self-esteem in senior high school students: a $\begin{array}{lllll}\text { cross-sectional study. Nordic Journal of Psychiatry, } & 72(2), & 84-88 .\end{array}$ https://doi.org/10.1080/08039488.2017.1389986

Singh, I., \& Jha, A. (2013). Anxiety, optimism and academic achievement among students of private medical and engineering colleges: a comparative study. Journal of Educational and Developmental Psychology, 3(1), 222-233. https://doi.org/10.5539/jedp.v3n1p222

Sugiyanto, E. P., Prasetyo, C. H., \& Pramono, W. H. (2020). Factors related to students' psychosocial problems during COVID-19 pandemic. Indonesian Journal of Global Health Research, 2(4), 309-314.

Talwar, P., Matheiken, S., Cheng, J. L. A., \& Sabil, S. (2019). Reliability and Factor Structure of the Westside Test Anxiety Scale among University Students. Online J. Health Allied Scs., 18(3), 8. Retrieved from https://www.ojhas.org/issue71/2019-3-8.html

von der Embse, N., Jester, D., Roy, D., \& Post, J. (2018). Test anxiety effects, predictors, and correlates: A 30-year meta-analytic review. Journal of affective disorders, 227, 483-493. https://doi.org/10.1016/j.jad.2017.11.048

Wachelka, D., \& Katz, R. C. (1999). Reducing test anxiety and improving academic self-esteem in high school and college students with learning disabilities. Journal of behavior therapy and experimental psychiatry, 30(3), 191-198. https://doi.org/10.1016/S0005-7916(99)00024-5

World Health Organization. (2020). Mental health and psychosocial considerations during the COVID-19 outbreak, 18 March 2020 (No. WHO/2019-nCoV/Mental Health/2020.1).

Yoon, S. U., \& Kwon, Y. S. (2015). Relationship between test anxiety and self-esteem in partial health related department convergence College students. Journal of the Korea Convergence Society, 6(5), 91-98. https://doi.org/10.15207/JKCS.2015.6.5.091

Yüksel, M. Y., Sevim, E., \& Çelimli, Ç. (2018). Examination of the Relationship Between Test Anxiety and Selective Attention Among Adolescents. Ilkogretim Online, 17(2), 864-873. https://doi.org/10.17051/ilkonline.2018.419331

Zhang, Y., Zhang, H., Ma, X., \& Di, Q. (2020). Mental Health Problems during the COVID-19 Pandemics and the Mitigation Effects of Exercise: A Longitudinal Study of College Students in China. International Journal of Environmental Research and Public Health, 17(10), 3722. https://doi.org/10.3390/ijerph17103722

\section{Copyrights}

Copyright for this article is retained by the author(s), with first publication rights granted to the journal.

This is an open-access article distributed under the terms and conditions of the Creative Commons Attribution license (http://creativecommons.org/licenses/by/4.0/). 